\title{
Mechanical properties of hydroxyapatite-dispersed magnesium composites
}

\author{
Hiroyuki WATANABE*, Naoko IKEO** and Toshiji MUKAI***
}

\begin{abstract}
The magnesium composites containing hydroxyapatite (HA) particles were synthesized. Unreacted Mg/HA composites were successfully fabricated by extruding the two component powders. The Young's modulus and strength of the extruded composites were lower than that of extruded magnesium, whereas the damping capacity of the composite was superior to that of extruded magnesium over the entire strain range examined. Microstructural observation of the composite containing $10 \mathrm{vol} \% \mathrm{HA}$ revealed that HA agglomerates with the size of $10-15 \mu \mathrm{m}$ were formed during the fabrication. The mechanical properties of the composites were closely associated with the HA agglomeration.
\end{abstract}

(Received January 12, 2016 Accepted March 14, 2016)

Keywords: magnesium-based composites, biodegradable metals, damping properties, mechanical properties

\section{1. 緒言}

水酸アパタイト $\mathrm{Ca}_{10}\left(\mathrm{PO}_{4}\right)_{6}(\mathrm{OH})_{2}$ (以下, $\left.\mathrm{HA}\right)$ は骨の無機 成分であり，骨と直接結合する生体活性セラミックとして知 られている。すでに，使用部位に合わせた形状・構造の人工 骨が整形外科や脳神経外科, 口腔外科などを中心に臨床使用 されている ${ }^{1)}$ 。一方, マグネシウムは, 生体内分解性金属と しての利用への期待が高まっており，骨接合材などへの応用

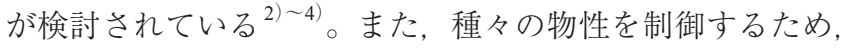
$\mathrm{HA}$ 粒子を分散させたマグネシウム基複合材料 ${ }^{5)}$ ９）が生体材 料への適用を目指して作製されてきた。HA分散複合材料は, HA 分散の困難さから粉末治金ルートによる作製 ${ }^{5), 8), 9)}$ が主 に試みられている。

HA 分散マグネシウム（合金）基複合材料は，耐食性， 機械的特性, 細胞毒性などの観点から評価されて, 生体 材料として有望な候補であることが示唆されている。例え ば，Witteら ${ }^{5)}$ は 20 mass\% の HA を Mg-9 mass\%Al-1 mass\%Zn （AZ91）合金に分散させた複合材料を作製し，複合化によっ て強度の向上, 疑似体液中での耐食性の向上がもたらされ, また細胞親和性を有する生体材料であると結論づけている。 $\mathrm{Gu} ら^{8)}$ は純マグネシウムと比較して，10 mass\%のHAを分 散させると強度の向上や疑似体液中での耐食性の向上が図ら れ，また複合材料には細胞毒性がなかったことを報告してい る。

生体セラミック分散マグネシウム基複合材料を例えば生体
内分解性を持つ骨接合材として利用することを念頭に置いた 場合，その機械的特性として強度特性のみならず，弾性率や 振動減衰特性も十分に考慮する必要がある。この理由は, 前 者は応力遮蔽効果に起因した骨萎縮への影響, 後者は振動や 繰り返し荷重に起因した骨組織の損傷・接合のゆるみへの影 響が懸念されるためである。しかしながら，これらの機械的 特性は詳細に検討されてこなかった。そこで本研究では水酸 アパタイト分散マグネシウム基複合材料を粉末治金ルートで 作製し, 弾性特性や振動減衰特性を含めた機械的特性につい て評価した。

\section{2. 実験方法}

\section{1 材料作製}

純度 $99.95 \%$ の純マグネシウム粉末（目開 $180 \mu \mathrm{m}$ 以下），お よびHA顆粒を入手した。HA顆粒の外観を走査型電子顕微 鏡 $(\mathrm{SEM})$ により観察した結果を Fig. 1aに示す。観察は, カー ボン両面テープで顆粒を固定して, JSM-6460LV（日本電子 株式会社）を用いて加速電圧 $15 \mathrm{kV}$ にて実施した。顆粒の直 径は $10 \mu \mathrm{m}$ 以下であった。しかし個々のHA顆粒の集合体は 乳鉢ですりつぶすだけで容易に一体化する特徴を持つ（Fig. 1b)。

マグネシウム粉末と HA 顆粒をHAの体積率が $10 \%$ となる ように秤量（HAの密度は $3.16 \mathrm{Mg} / \mathrm{m}^{3}$ とした）した。エタノー ルを添加した粉末をめのう乳鉢を用いて湿式にて手混合した 後, 乾燥させた。なお, 混合過程は粉末が均一に混合された

\footnotetext{
*大阪市立工業研究所加工技術研究部（一536-8553 大阪市城東区森之宮 1-6-50） Department of Processing Technology, Osaka Municipal Technical Research Institute (1-6-50 Morinomiya, Joto-ku, Osaka-shi, Osaka 536-8553) E-mail: hwata@omtri.or.jp

***神戸大学大学院工学研究科機械工学専攻（神戸市） Department of Mechanical Engineering, Graduate School of Engineering, Kobe University (Kobe-shi, Hyogo)

***神戸大学自然科学系先端融合研究環（神戸市） Organization of Advanced Science and Technology, Kobe University (Kobe-shi, Hyogo)
} 

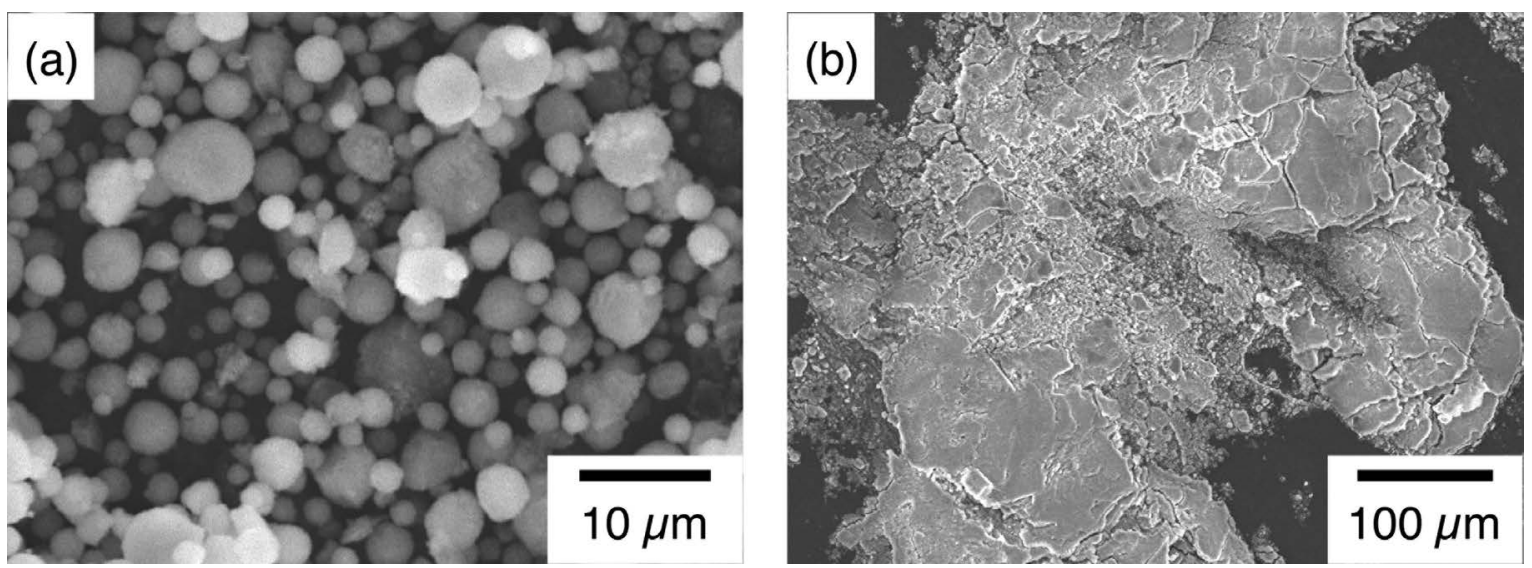

Fig. 1 SEM images of (a) as-received and (b) grounded hydroxyapatite granules.

ことが目視で確認できた段階で停止した。この混合粉末をマ グネシウム合金 (AZ31) 製の缶（内径 $37 \mathrm{~mm}$ ) に詰めた後,

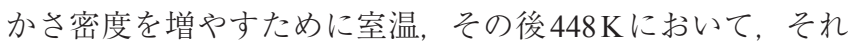
ぞれ $0.9 \mathrm{kN}, 1.6 \mathrm{kN}$ の荷重で圧粉した。

圧粉後の缶を丸棒形状に押出加工することで $10 \mathrm{vol} \%$ の $\mathrm{HA}$ が分散した複合材料 (以後, $\mathrm{Mg} / \mathrm{HA}$ 押出材) を作製した。 押出温度の決定に際しては，純マグネシウム粉末とHA顆粒 の混合粉末 (HA 体積率は 20\%) に対して, 熱重量測定 (TG)・ 示差熱分析（DTA）を実施した。TG-DTA測定時の昇温速度 は $10 \mathrm{~K} / \mathrm{min} と し$, DTA測定のリファレンスにはアルミナを

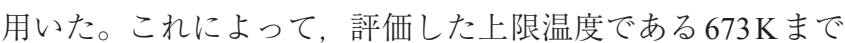
は化学変化・物理変化に関連するピークがないことをあらか じめ確認した。なお，後述のとおり今回作製した複合材料の HA 体積率は最大でも $10 \mathrm{vol} \%$ であるが，マグネシウムと HA が接触する頻度を高くし，化学変化・物理変化が起こった 場合の信号がより検知しやすくなることを期待してHA体積 率を20vol\%にした。押出温度はTG-DTAの結果に基づいて $623 \mathrm{~K}$ とし，また各種試験片の採取のために押出比は 16 とし た。

比較のため, マグネシウム粉末だけを押出加工することに より固化した純マグネシウムの丸棒（以後， Mg押出材）を 作製した。また，HA体積率を $5 \mathrm{vol} \%$ にした複合材料も作製 し，2.2節に記した評価の一部を実施した。

\section{2 材料組織と機械的特性の評価}

押出材の組織は，光学顕微鏡およびSEMで観察した。光 学顕微鏡組織観察では acetic-picral 液の一種（酢酸：10 mL, ピクリン酸： $7 \mathrm{~g}, \mathrm{H}_{2} \mathrm{O}: 10 \mathrm{~mL}$, エタノール：70 mL）をエッ チング液として用いた。SEMによる観察はJSM-6460LVを用 いて加速電圧 $15 \mathrm{kV}$ にて行った。 $\mathrm{Mg} / \mathrm{HA}$ 押出材中の結晶相の 同定は, $\mathrm{Cu}$ の $\mathrm{K} \alpha$ 線を用いた X 線回折（光学系：集中法，電 圧 : $40 \mathrm{kV}$, 電流 : $50 \mathrm{~mA}$ ）をRINT2500（理学電機株式会社） を用いて行った。

押出材の機械的特性（動的ヤング率，引張・圧縮特性，振 動減衰特性）の評価は室温（296K）において行った。いず れの試験片も押出材の円断面の中心が試験片の中心と一致す るように機械加工で採取し, 採取方向は押出の方向と一致さ せた。

動的ヤング率 $\left(E_{\mathrm{dyn}}\right)$ は, 自由共振法（JIS Z2280-1993に おける横共振法）によって1次の共振周波数（約 $2500 \mathrm{~Hz}$ )
から算出した。長さ $60 \mathrm{~mm}$, 幅 $7 \mathrm{~mm}$, 板厚 $1.8 \mathrm{~mm}$ の矩形試 験片を用いた。

引張，および圧縮試験は初期ひずみ速度 $5 \times 10^{-4} \mathrm{~s}^{-1}$ にて 行った。引張試験には平行部長さ $15 \mathrm{~mm}$, 直径 $3 \mathrm{~mm}$ の棒状 試験片を, 圧縮試験には高さ $8 \mathrm{~mm}$, 直径 $4 \mathrm{~mm}$ の円柱試験片 を用いた。引張ひずみは伸び計を用いて計測した。圧縮ひず みは試験機の弾性変形を考慮して算出した。 $0.2 \%$ 耐力 $\left(\sigma_{0.2}\right)$, および $0.5 \%$ 耐力 $\left(\sigma_{0.5}\right)$ をオフセット法によって算出した。

振動減衰特性は, 試験方法として共振法を採用して評価 した。動的ヤング率を測定した試験片を用いた。試験片保 持は片端固定として, 試験片を曲げモードで1次の共振周波 数 (約 $14 \mathrm{~Hz}$ ) において加振させ, 加振力を除去した後の減 衰から損失係数 $(\eta)$ を算出した。

\section{3. 結果}

\section{1 材料組織}

$\mathrm{Mg}$ 押出材の光学顕微鏡組織を Fig. 2aに示す。元々のマグ ネシウム粒子表面が判別できないほど良好に固化されてい る。また, 微細な結晶粒の領域 (約 $3 \mu \mathrm{m})$ と比較的粗大な 結晶粒の領域 $(15 \mu \mathrm{m})$ から構成されるが, いずれの大きさ の結晶粒も押出方向には伸長していなかった。

$\mathrm{Mg} / \mathrm{HA}$ 押出材の光学顕微鏡組織（エッチングあり）を Fig. $2 \mathrm{~b}$ に, SEMの組成像（エッチングなし）を Fig. 2ck示す（そ れぞれで異なる領域を観察)。

$\mathrm{Mg} / \mathrm{HA}$ 押出材の母相の結晶粒（Fig. 2b）は, HA 分散によっ て微細化せず, $\mathrm{Mg}$ 押出材で観察された約 $3 \mu \mathrm{m}$ の微細な結晶 粒も観察されない。

$\mathrm{Ca}$ の化合物である HA は組成像（Fig. 2c）では明るい領 域に存在しており, 図中の白矢印で示したような HAが薄 く引き延ばされている領域と, 眓中の黒矢印で示したよう な 10〜 $15 \mu \mathrm{m}$ 程度に凝集している領域が存在することがわ かる。Fig. 2bの黒い部分はHAが存在する領域に対応してお り, 押出前には個々のマグネシウム粒子表面を覆っていた HAが，分断されないまま押出方向と平行に引き延ばされた 結果として形成された分布形態であると考えられる。このよ うなHAの分布は, 個々のHA顆粒の集合体が容易に一体化 する（Fig. 1b）ことに起因する。

$\mathrm{Mg} / \mathrm{HA}$ 押出材について, 押出方向と平行な面で得られた X線回折プロファイルをFig. 3 に示す。図には Mg 相と HA 相 

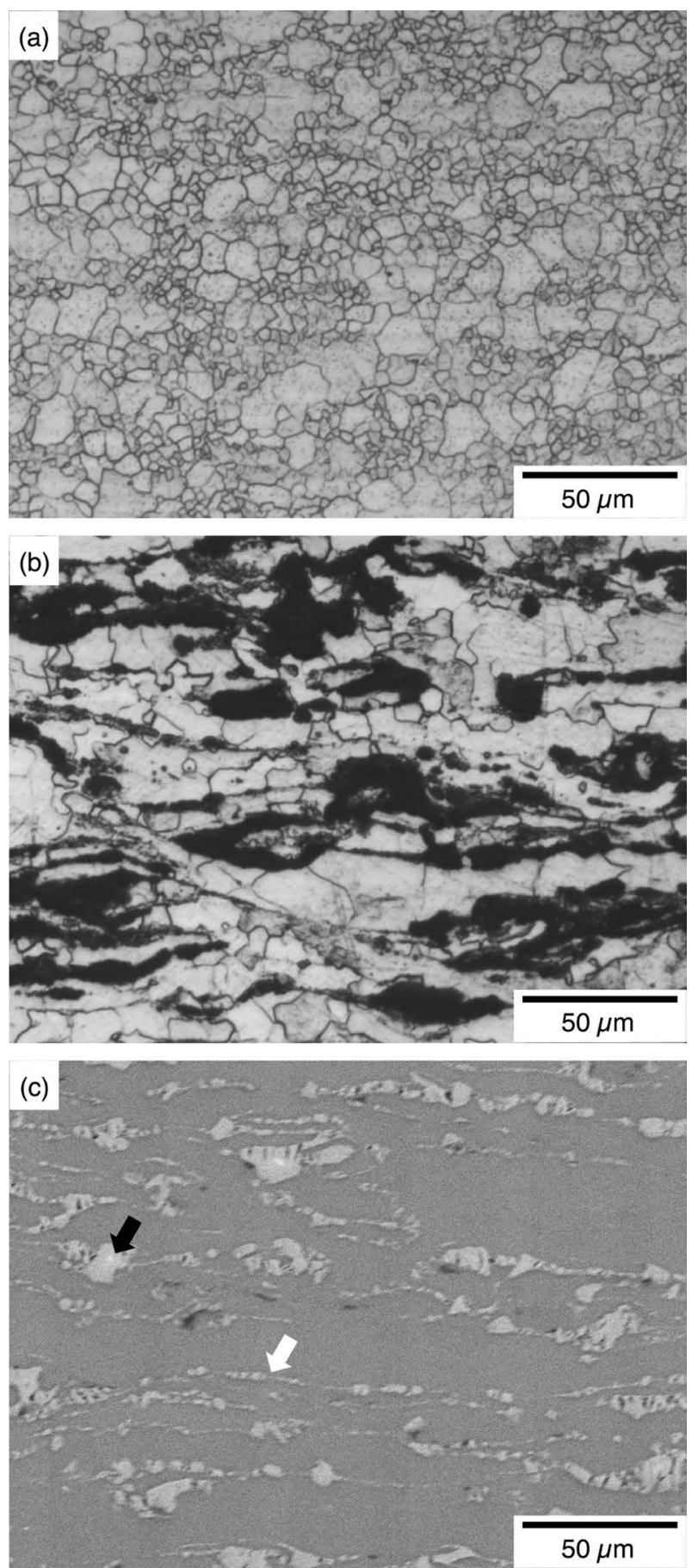

Fig. 2 Optical microstructures of (a) extruded magnesium and (b) extruded $\mathrm{Mg} / \mathrm{HA}$ composite. (c) Backscattered electron (Compo) image of extruded $\mathrm{Mg} / \mathrm{HA}$. Extrusion direction for each material is horizontal.

のピークしか現れていないことから，複合材料作製の過程で $\mathrm{HA}$ の化学反応がなかったと判断できる。なお， $\mathrm{Mg}$ 押出材 および $\mathrm{Mg} / \mathrm{HA}$ 押出材に関して, 押出方向と平行な面で得ら れたX線回折プロファイルの（100），(002），(101）反射強 度から判断して, 両材料とも底面が押出方向と平行に配向し た集合組織が形成されていると考えられた。

\section{2 弾性, および引張・圧縮特性}

$\mathrm{Mg}$ 押出材および $\mathrm{Mg} / \mathrm{HA}$ 押出材の動的ヤング率を Table 1 に示す。HA分散に伴ってヤング率は低下した。

$\mathrm{Mg}$ 押出材および $\mathrm{Mg} / \mathrm{HA}$ 押出材の微小ひずみ領域におけ

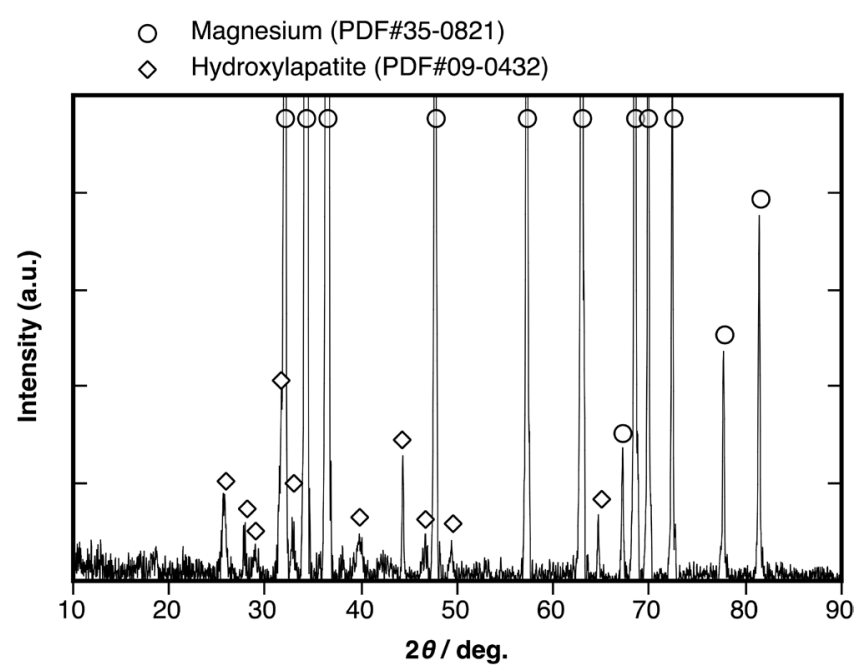

Fig. 3 XRD profile of extruded $\mathrm{Mg} / \mathrm{HA}$ composite.
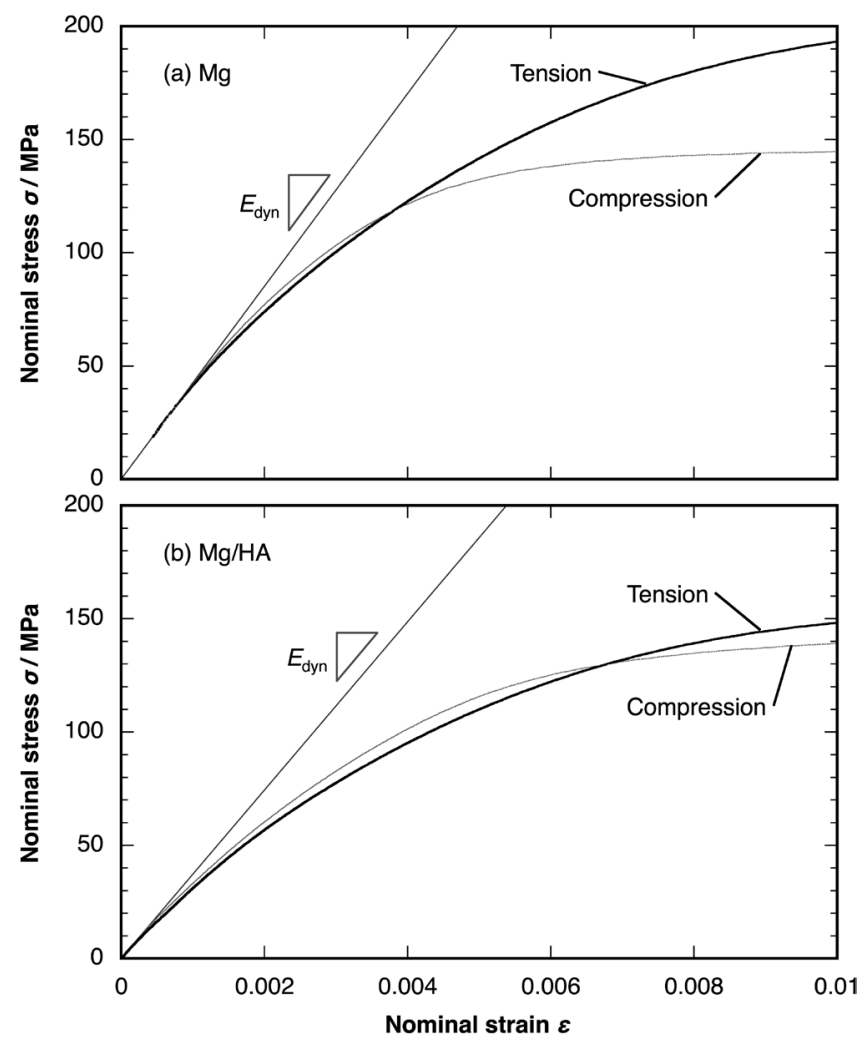

Fig. 4 Stress-strain curves at low strains of (a) extruded magnesium and (b) extruded $\mathrm{Mg} / \mathrm{HA}$ composite. The straight lines have a slope equal to the dynamic Young's modulus listed in Table 1.

Table 1 Dynamic Young's modulus of extruded magnesium and extruded $\mathrm{Mg} / \mathrm{HA}$ composite.

\begin{tabular}{c|c}
\hline \hline Material & $E_{\text {dyn }}(\mathrm{GPa})$ \\
\hline $\mathrm{Mg}$ & 42.5 \\
$\mathrm{Mg} / \mathrm{HA}$ & 37.1 \\
\hline
\end{tabular}

る応力ーひずみ曲線を Fig. 4 に示す。原点を通る直線の傾 き $\left(E_{\mathrm{dyn}}\right)$ は, 実測した動的ヤング率を表している。 $\mathrm{Mg}$ 押 出材および $\mathrm{Mg} / \mathrm{HA}$ 押出材の比例限度はそれぞれ約 $40 \mathrm{MPa}$ お 
Table 2 Yield strengths under tension $\left(\sigma^{\mathrm{T}}\right)$ and compression $\left(\sigma^{\mathrm{C}}\right)$ of extruded magnesium and extruded $\mathrm{Mg} / \mathrm{HA}$.

\begin{tabular}{l|c|c|c|c}
\hline \hline Material & $\sigma_{0.2}^{\mathrm{T}}(\mathrm{MPa})$ & $\sigma_{0.5}^{\mathrm{T}}(\mathrm{MPa})$ & $\sigma_{0.2}^{\mathrm{C}}(\mathrm{MPa})$ & $\sigma_{0.5}^{\mathrm{C}}(\mathrm{MPa})$ \\
\hline $\mathrm{Mg}$ & 150 & 190 & 134 & 143 \\
$\mathrm{Mg} / \mathrm{HA}$ & 110 & 144 & 118 & 137 \\
\hline
\end{tabular}

Table 3 Tensile strength $\left(\sigma_{\mathrm{TS}}\right)$ and elongation $\left(e_{\mathrm{f}}\right)$ of extruded magnesium and extruded $\mathrm{Mg} / \mathrm{HA}$.

\begin{tabular}{l|c|c}
\hline \hline Material & $\sigma_{\mathrm{TS}}(\mathrm{MPa})$ & $e_{\mathrm{f}}(\%)$ \\
\hline $\mathrm{Mg}$ & 218 & 4 \\
$\mathrm{Mg} / \mathrm{HA}$ & 155 & 1 \\
\hline
\end{tabular}

よび約 $15 \mathrm{MPa}$ であった。それぞれの押出材の耐力を Table 2 に示す。

$\mathrm{Mg}$ 押出材と $\mathrm{Mg} / \mathrm{HA}$ 押出材の変形挙動の違いを比較する と, $\mathrm{Mg} / \mathrm{HA}$ 押出材の比例限度, $0.2 \%$ 耐力, $0.5 \%$ 耐力が $\mathrm{Mg}$ 押出材よりも低くなっている。今回作製した複合材料におい て, HA分散は複合強化にまったく寄与していないと考えら れる。

次にそれぞれの押出材について引張変形と圧縮変形の 挙動を比較する。 $\mathrm{Mg}$ 押出材では, 引張変形と圧縮変形 の応力差がひずみとともに $16 \mathrm{MPa}(0.2 \%$ 耐力の時）から $47 \mathrm{MPa}(0.5 \%$ 耐力の時）にまで広がっている。マグネシウ 厶展伸材を加工方向（例えば押出方向）と平行な方向に一軸 変形した場合, 引張双晶の形成に起因して圧縮時の応力が 引張時の応力よりも低くなるという挙動がよく知られてい る ${ }^{10)}$ 。 $\mathrm{Mg}$ 押出材でも $0.2 \%$ 耐力に到達する少し前のひずみか ら引張双晶が形成されることで, 圧縮応力の方が低くなって いると考えられる。一方, $\mathrm{Mg} / \mathrm{HA}$ 押出材 (Fig. 4b) では引張 変形時と圧縮変形時の応力ーひずみ関係にほとんど違いが認 められなかった。複合材料におけるこのような引張／圧縮応 力の非対称性の解消は, リン酸タングステン酸ジルコニウム $\mathrm{Zr}_{2}\left(\mathrm{WO}_{4}\right)\left(\mathrm{PO}_{4}\right)_{2}$ を分散したマグネシウム基複合材料でも報 告されており, 圧縮変形における双晶形成が抑制された結果 であった ${ }^{11)} 。 \mathrm{Mg} / \mathrm{HA}$ 押出材でも双晶形成の抑制効果によっ て引張／圧縮の非対称性が解消されていると推測される。

$\mathrm{Mg}$ 押出材および $\mathrm{Mg} / \mathrm{HA}$ 押出材の引張強さ, および引張破 断伸びを Table 3 に示す。HA分散に伴って引張強さも伸びも 著しく低下した。

\section{3 振動減衰特性}

$\mathrm{Mg}$ 押出材および $\mathrm{Mg} / \mathrm{HA}$ 押出材における損失係数の振幅ひ ずみに伴う変化を Fig. 5 に示す。振幅ひずみは引張・圧縮変 形において比例限度に達するひずみよりも小さい領域で評価 している。ひずみの増加に伴う損失係数の増加はどちらの材 料も小さく, 損失係数は振幅ひずみに不敏感であった。 $\mathrm{Mg} /$ HA 押出材の損失係数は，測定したひずみ域にわたって， Mg 押出材のそれよりも約 1.5 倍高い值を示し, HA分散によっ て減衰能は向上した。

\section{4. 考察}

\section{1 ヤング率および耐力に及ぼすHA 分散の影響}

$\mathrm{HA}$ のング率は 73〜 $117 \mathrm{GPa}^{22)}$ でありマグネシウムより

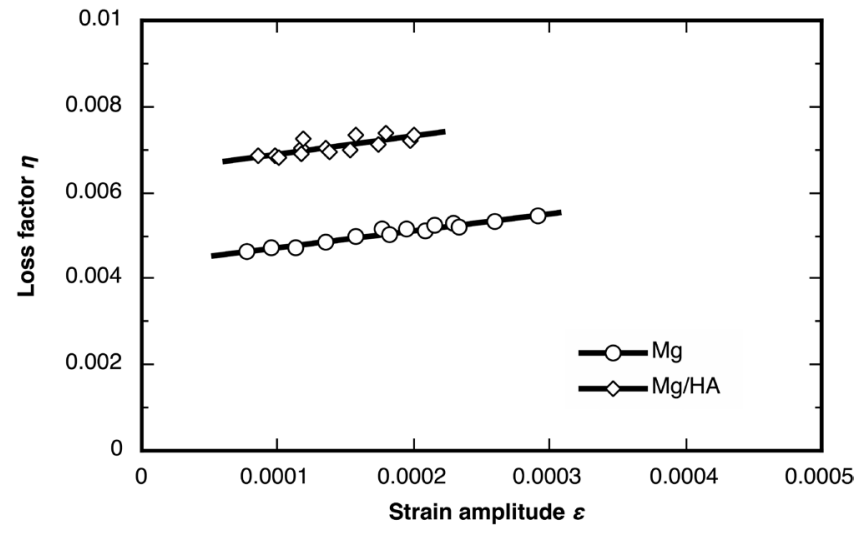

Fig. 5 Variation in loss factor with strain amplitude of extruded magnesium and extruded $\mathrm{Mg} / \mathrm{HA}$ composite.

も高いことから, 球状粒子分散型複合材料の弾性率を予測す る Hashinのモデル ${ }^{13)}$ に基づけば $\mathrm{Mg} / \mathrm{HA}$ 押出材のヤング率は $\mathrm{Mg}$ 押出材よりも高くなるはずである。しかしながら Table 1 に示したとおりHAの複合化によってヤング率は低下してい る。HAの体積率に伴うヤング率の変化を Fig. 6aに示す。図 には, 本研究で粉末治金ルートにより作製したHA体積率が $5 \mathrm{vol} \%$ の $\mathrm{Mg} / \mathrm{HA}$ 複合材料, および AZ91合金と AZ91/HA 複 合材料の文献值 ${ }^{5)}$, 14) を含めた。ヤング率はHA 体積率の増 加とともに直線的に減少していることがわかる。本研究で作 製した複合材料と同様にAZ91/HA 複合材料においても最大 $20 \mu \mathrm{m}$ のイズにHAが凝集している ${ }^{5)}$ 。よって, Fig. 6 に示 した複合材料が球状粒子分散型複合材料の弾性率則に従わな い（ヤング率が増加しない）原因はHAの凝集に起因すると 推測される。

HAの体積率に伴う $0.2 \%$ 耐力（引張）の変化を Fig. $6 \mathrm{~b}$ に示 す。図には，本研究で作製した HA体積率が 5 vol\%の Mg/HA 複合材料の結果を含めた。我々の複合材料の耐力はHA量の 増加とともに単調に減少していく傾向がある。HA分散にも かかわらず母相の結晶粒が微細化されなかったこと (Fig. 2)， およびHAが一部で凝集していることに起因して複合強化が 働かなかったことの二つが要因であると考えられる。

Fig. 6bには，HAを分散させた純マグネシウム基複合材料 の文献值 ${ }^{6), 8)}$ も含めた。これらの複合材料では約 $5 \mathrm{vol} \%$ で 耐力が最大值を示した後, 低下していく傾向がある。Khanra $ら^{6)}$ が鋳造ルートでHAを複合化し，その後押出加工を行っ て得た $\mathrm{Mg} / \mathrm{HA}$ 複合材料では, $\mathrm{HA}$ 量の増加に伴って母相の結 晶粒径は微細化したが，30〜100 $\mu \mathrm{m}$ 程度の大きさのHAの凝 集が観察されている。Khanra $5^{6), 7)}$ はHA複合化による強化 機構を指摘しているが, 実際には母相の結晶粒微細化による 強化と HA 複合化による弱化の兼ね合いで強度が決定してい たと予想される。以上のことから，HA凝集が存在する限り はHA分散による複合強化は期待できない。 

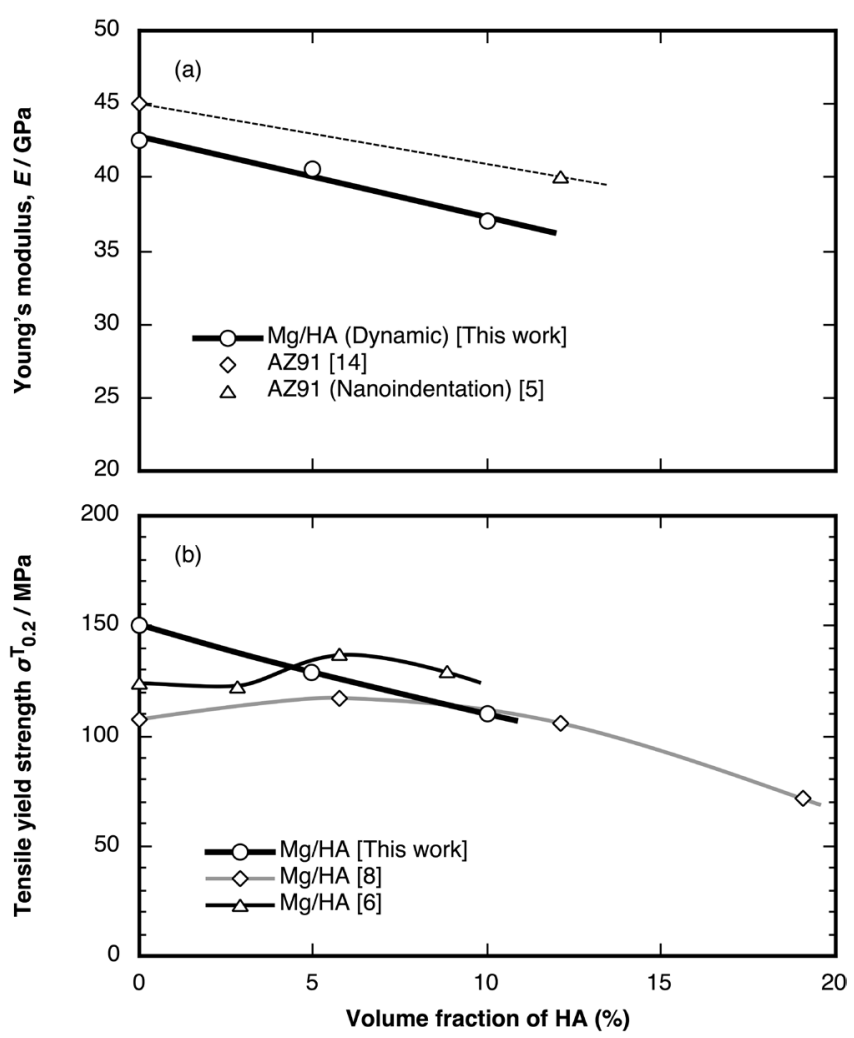

Fig. 6 Variations in (a) Young's modulus and (b) tensile yield strength with volume fraction of $\mathrm{HA}$ in magnesiumbased composites.

\section{2 振動減衰能に及ぼすHA 分散の影響}

マグネシウムに減衰能を与える機構として（1）転位に 基づく内部摩擦が重要であり, 特に底面〈a〉転位の運動が 起こりやすいと減衰能が向上すると指摘されている ${ }^{15)} 。 こ$ れに加えて，(2) 熱弾性効果 ${ }^{16)}$ および（3）双晶界面の移

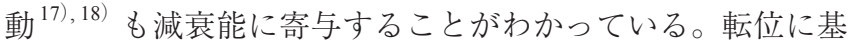
づく内部摩擦は, (1-a) 振幅ひずみに不敏感な, 転位の共鳴 による機構と，（1-b）振幅ひずみに強く依存する転位のヒス テリシスによる機構に分類 ${ }^{19), 20)}$ され，低ひずみ域では前者 が支配的であり，引張／圧縮変形における比例限度以上の高 ひずみ域になると後者が重畳してくる ${ }^{15)}$, 21)。複合材料の場 合には，複合型（例えば，片状黒鉛鋳鉄がこの機構に分類さ れる）が減衰機構として加わる。

$\mathrm{Mg}$ 押出材における損失係数は, 引張 /圧縮変形における 比例限度以下に対応するひずみで測定されていることから， 熱弾性効果，および振幅ひずみに不敏感な転位に基づく内部 摩擦が振動減衰機構として働いていると考えられる。一方, $\mathrm{Mg} / \mathrm{HA}$ 押出材においては, これらに加えて, 複合型の機構 が重畳していると，片状黒鉛鋳鉄における挙動から類推でき る。片状黒鉛鋳鉄においては炭素当量（共晶近傍の炭素当量 まで）とともにヤング率は低下し ${ }^{22)}$ ，一方で，減衰能は向 上することがわかっており ${ }^{23)}$ ，これらの変化は $\mathrm{Mg} / \mathrm{HA}$ 複合 材料で得られた結果と一致する。また，片状黒鉛鋳鉄は黒鉛 の大きさが微細でない方が減衰能が高くなることもわかって いる ${ }^{24)}$ 。よって, HAの凝集は複合型の機構を有効に働かせ て, 減衰能を 1.5 倍向上させる要因になったと考えられる。

複合型の振動減衰機構として, 片状黒鉛鋳鉄では片状黒鉛 のミクロな塑性変形（van del Waals 力で弱く結合している底
面間でのずれ振動など）が候補の一つに挙げられている ${ }^{25)}$ が, $\mathrm{Mg} / \mathrm{HA}$ 複合材料ではHA凝集部のミクロな塑性変形が 以下の理由により重要であると考えられる。HA粉末の焼 結は一般的には $1273 \mathrm{~K}$ 以上の温度において行われるが, 緻 密化は $1073 \mathrm{~K}$ 以上の温度から進行することが報告されてい る $^{26)}$ 28)。 $\mathrm{Mg} / \mathrm{HA}$ 押出材は押出温度 $623 \mathrm{~K} て ゙$ 固化しており, HA 粒子の緻密化が進行する温度よりも $450 \mathrm{~K}$ 以上低い。こ れらのことから推測すると, $\mathrm{Mg} / \mathrm{HA}$ 複合材料の $\mathrm{HA}$ 凝集部に おいて HA 粒子の焼結（バルク化）はほとんど進行せずに， HA 粒子は焼結されない状態で集合しているはずである。HA 顆粒の集合体が容易に一体化すること（Fig. 1b）も合わせて 考えると, 低い振幅ひずみ領域でも HA凝集部のミクロな塑 性変形が容易に生じると予想される。

\section{5. 結言}

純マグネシウムと HAの混合粉末を押出加工によって固化 することにより HA 分散マグネシウム基複合材料を作製し た。得られた複合材料について, 引張・圧縮変形特性だけで なく, これまで検討されてこなかった弾性特性や振動減衰特 性も評価した。

$\mathrm{Mg} / \mathrm{HA}$ 押出材のヤング率と強度（比例限度, 耐力）は $\mathrm{Mg}$ 押出材の值よりも低かったが, 振動減衰能は $\mathrm{Mg} / \mathrm{HA}$ 押出 材の方が約 1.5 倍高い值を示した。 $\mathrm{Mg} / \mathrm{HA}$ 押出材には 10 $15 \mu \mathrm{m}$ 程度の大きさの HAの凝集が一部で観察され, この凝 集が機械的特性に影響を与えていると考えられた。

HA 分散によってマグネシウム基複合材料のヤング率が皮 質骨のヤング率 $\left(3 \sim 30 \mathrm{GPa}^{12)}\right)$ に近付き，そして振動減衰 能が向上するという結果は, 作製した複合材料が骨接合材の 素材として有望なことを示唆している。

\section{謝 辞}

材料作製および機械的特性の評価を行った神戸大学大学 院工学研究科機械工学専攻大学院生 澤田忠明氏に感謝す る。本研究の一部はJSTP科研費 24560810 の助成により実施 した。

\section{参 考 文 献}

1) 中島武彦：セラミックス, 43 (2008), 984-986,

2) N. Erdmann, N. Angrisani, J. Reifenrath, A. Lucas, F. Thorey, D. Bormann and A. Meyer-Lindenberg: Acta Biomater., 7 (2011), 14211428 .

3) H. Waizy, A. Weizbauer, M. Maibaum, F. Witte, H. Windhagen, A. Lucas, B. Denkena, A. Meyer-Lindenberg and F. Thorey: J. Mater. Sci. Mater. Med., 23 (2012), 649-655.

4) N. Ikeo, J. Shimizu, C. Ishigaki, Y. Sano, Y. Shimizu and T. Mukai: Magnesium Technology 2015, ed. by M. V. Manuel, A. Singh, M. Alderman and N. R. Neelameggham, Wiley, (2015), 399-402.

5) F. Witte, F. Feyerabend, P. Maier, J. Fischer, M. Störmer, C. Blawert, W. Dietzel and N. Hort: Biomaterials, 28 (2007), 2163-2174.

6) A. K. Khanra, H. C. Jung, S. H. Yu, K. S. Hong and K. S. Shin: Bull. Mater. Sci., 33 (2010), 43-47.

7) A. K. Khanra, H. C. Jung, K. S. Hong and K. S. Shin: Mater. Sci. Eng. A, 527 (2010), 6283-6288.

8) X. Gu, W. Zhou, Y. Zheng, L. Dong, Y. Xi and D. Chai: Mater. Sci. Eng. C, 30 (2010), 827-832.

9) S. Z. Khalajabadi, M. R. Abdul Kadir, S. Izman and M. Marvi: J. Alloys Compd., 655 (2015), 266-280.

10) M. R. Barnett, Z. Keshavarz, A. G. Beer and D. Atwell: Acta Mater., 42 (2004), 5093-5103.

11) H. Watanabe, J. Tani, H. Kido and K. Mizuuchi: Mater. Sci. Eng. A, 
494 (2008), 291-298.

12) T. Thamaraiselvi and S. Rajeswari: Trends Biomater. Artif. Organs, 18 (2004), 9-17.

13) Z. Hashin: J. Appl. Mech., 29 (1962), 143-150.

14) ASM Specialty Handbook: Magnesium and Magnesium Alloys, ed. by M.M. Avedesian and H. Baker, ASM International, (1999) 232.

15) H. Watanabe, T. Sawada, Y. Sasakura, N. Ikeo and T. Mukai: Scr. Mater., 87 (2014), 1-4.

16) H. Watanabe, T. Mukai, M. Sugioka and K. Ishikawa: Scr. Mater., 51 (2004), 291-295.

17) H. Watanabe, Y. Sasakura, N. Ikeo and T. Mukai: J. Alloys Compd., 626 (2015), 60-64.

18) Y. Cui, Y. Li, S. Sun, H. Bian, H. Huang, Z. Wang, Y. Koizumi and A. Chiba: Scr. Mater., 101 (2015), 8-11.

19) A. Granato and K. Lücke: J. Appl. Phys., 27 (1956), 583-593.
20) A. Granato and K. Lücke: J. Appl. Phys., 27 (1956), 789-805.

21）渡辺博行，笹倉康義，向井敏司：日本金属学会誌, 78（2014）, 230-234.

22）松井 啓, 高橋 睦, 寄高政史：鋳物, 45（1973）， 508-516.

23）松井 啓, 松野 亮, 木津文生, 高橋 睦, 菅野秀雄：日本金 属学会誌, 40 (1976), 1062-1068.

24) M. A. O. Fox and R. D. Adams: J. Mech. Eng. Sci., 15 (1973), 81-94.

25) 制振材料：その機能と応用, 編集田中良平, 日本規格協会, (1992), 55-59.

26) N. Y. Mostafa: Mater. Chem. Phys., 94 (2005), 333-341.

27) D. Malina, K. Biernat and A. Sobczak-Kupiec: Acta Biochim. Pol., 60 (2013), 851-855.

28) S. Ramesh, K. L. Aw, R. Tolouei, M. Amiriyan, C. Y. Tan, M. Hamdi, J. Purbolaksono, M. A. Hassan and W. D. Teng: Ceram. Int., 39 (2013), 111-119. 